\title{
French language societies: purist or moderate?
}

\author{
Olivia Walsh \\ Clare College \\ University of Cambridge \\ omw23@cam.ac.uk
}

\section{Introduction}

The second half of the twentieth century has seen the emergence in France of an increasing number of private societies for the defence of the French language. Since the 1990s, new societies have increasingly been established online, with older societies also creating an online presence. A study of the various societies has highlighted their two major preoccupations: the status and use of the French language in both France and the EU and the influence of English on the French language. These relate to two aims, respectively, the promotion and the protection of the French language.

Attempts to promote or protect the French language are not new, as the existence of the Académie française (founded in 1635) makes clear. Indeed, as far as protecting the language is concerned, France is a country that has long been associated with linguistic purism. Can these new language societies be seen to represent a modern-day form of linguistic purism? Or are they merely a reflection of the 'crise du français' which is often claimed to exist in current day France, a result of the loss of the privileged status once enjoyed by the French language and the related reduction in political power that France once possessed (cf. Adamson, 2007: xi-xx)?

In order to answer this question, it is necessary to first define what is meant by linguistic purism and to determine a means of measuring this. This study takes as its base George Thomas's Linguistic Purism, which provides 'the first broadly comparative and cross-cultural study of purism' and establishes a theoretical framework for purism outlining the elements typical of all purist movements. These elements are then incorporated in a questionnaire which serves as a checklist of characteristics which can be used to compile a profile of purism in a given language. The language societies will be analysed in terms of this framework to see whether they reflect the rationales provided for purism in Thomas's work and can thus be considered to represent a current purist movement in France.

The space in this article does not allow for an evaluation of all of the language societies surveyed. As all of the societies reflect the two major themes outlined above, but do so to quite different degrees, two societies which lean more heavily towards one and the other theme have been chosen, to provide two typical case studies of the preoccupations and activities of the societies in general.

A definition of purism is first given here, followed by an overview of the two language societies before Thomas's checklist is outlined and then applied to the language societies.

\subsection{Definition of purism}

The general, broad definition of linguistic purism provided by Thomas (1991:2) will be taken as the basis for this discussion. Thomas defines purism as:

the manifestation of a desire on the part of the speech community (or some section of it) to preserve a language from, or rid it of, putative foreign elements held to be undesirable (including those originating in dialects, sociolects and styles of the same language). It may be directed at all linguistic levels, but primarily the lexicon. Above all, it is an aspect of the codification, cultivation and planning of standard languages. 
Purism thus involves the following ideas:

- Only one form of the language is the correct (or even, the 'perfect') form (generally this form is the standard form)

- This language is currently pure and, therefore, change to this form equals contamination, corruption or decline of some sort

- The language must be protected from this contamination and preserved in its current state (or, alternatively, if the language has already begun to be corrupted, the corrupted part must be removed).

\section{The online language societies}

The Défense de la langue française (DLF) and the Avenir de la langue française (ALF) are both private language societies whose aims are to defend and promote the French language. However, although the overall aims of these societies appear to be very similar, and they carry out some activities in tandem, they also differ on many levels.

\subsection{Défense de la langue française (DLF)}

\subsubsection{Overview}

The DLF was founded in 1958 and its general aim is the defence and spread of the French language at both the national and international level. More specifically, the DLF states its aims as follows:

- Ensuring that the French can access information in French and can use French for all areas of life in France.

- Safeguarding those qualities which for so long have given the French language its superiority among the European languages, in particular opposing the 'uncontrolled and harmful invasion' of foreign terms.

- Slowing down the 'anarchic' invasion of foreign terms.

- Enriching the French language and adapting it to modern life.

- Working at spreading the influence of French in the world. ${ }^{1}$

The language used here by the DLF to outline its aims is quite strongly purist. For example, it refers to the 'superiority' of French (the idea of language having a perfect form) and to the harmful invasion of foreign terms (the danger of contamination of this superior form). It is interesting, however, that not all of the society's aims correspond to this clearly purist stance. For example, although the 'anarchic invasion' of foreign terms is referred to, the aim is not to completely stop this invasion, but rather to 'slow it down'. Also, the aim to enrich the language would appear to be the opposite of protecting it from change and keeping it in its current 'perfect' state. It may be, of course, that the stated aims of the society do not reflect the reality. As Thomas points out, there may be 'contradictions between the proclaimed and publicly recognised motives for their language behaviour and the actual reasons and motives' (1991: 38). Examining the various activities of the society may allow us to gain some insight into this issue.

\subsubsection{Activities}

The DLF has several 'cercles' which group together members with different interests, such as the Cercle Ambroise-Paré, a group for those interested in French in the medical domain and the Cercle des journalistes, a group for those interested in French in the media. There are also some circles that play a more active role. For example, the objective of the Cercle des Enfants is 'd'ouvrir des bibliothèques pour les enfants (jusqu'à 12 ans) dans les pays qui souhaitent s'initier à la langue française ou la promouvoir' and that of the Cercle Philippe-Sengor is 'd'illustrer l'invention et la créativité en langue française des élèves des écoles élémentaires francophones' by running a competition every year called the concours scolaire francophone, which is open to all students in the final years of primary school in Francophone 
schools. ${ }^{2}$ It is interesting that these activities are aimed at young children: this is clearly an attempt by the DLF to pass on its values to a younger generation.

The DLF website also has a musée des horreurs section which is dedicated to photographs of English words used in a French context. The language used to describe this section of the site is negative and emotive to an extreme and reflects an extremely purist attitude towards the use of English in France or in French:

\begin{abstract}
Par bêtise, par snobisme, par imitation servile, la langue française est chaque jour bafouée et chassée au profit du sabir anglo-américain. Cette anglopathie américanoïde spongiforme se manifeste dans la rue, dans nos journaux, dans nos entreprises et dans nos universités. Partout où la langue française avait gagné une place internationale, elle est défaite par l'anglais avec la complicité active de certaines de nos élites publiques ou privées. Il fallait rassembler en un seul lieu d'exposition quelques-unes de ces manifestations scandaleuses d'abandon de notre langue. ${ }^{3}$
\end{abstract}

Finally, the DLF also compiles a monthly relevé d'écoute, that is, a list of French 'errors' or anglicisms heard on the radio or television, or seen in the written media, with one or more French alternatives or corrections provided for each of these. These lists are available on the website. It is not clear from the lists how many members contribute to them, or who edits them, but they nonetheless provide an interesting insight into the areas of language that interest (or concern) the members of this society. ${ }^{4}$

Taking all of the relevé d'écoute lists from 2008 as an example allows us to highlight some of the main issues preoccupying members of this society. During this period 744 complaints were noted and, of these, over two thirds $(66.5 \%)$ were complaints about anglicisms, with some anglicisms in particular being targeted over and over again. For example, the six terms 'casting', 'trader', 'people', 'coach', 'design' and 'email' alone make up nearly a quarter of the complaints about anglicisms. It may be that these terms were in particularly widespread use during the period in question, or simply that they are for some reason particularly salient to those compiling these lists. Of the general complaints noted (nearly one third of the total), the majority include complaints about vocabulary (using ramener for rapporter, using périple for a general journey rather than a journey by sea), question word order (using intonation instead of inversion, for example Comment on peut les voir? instead of Comment peut-on les voir?), tense/mood (complaints exclusively about using the subjunctive instead of the indicative after après que) and gender (both nominal gender, such as la seule antidote instead of le seul antidote, and gender agreement, almost exclusively with regard to preceding direct objects, such as 'une opposition que le ministre du logement 'a fait', instead of 'a faite').

These lists of complaints are interesting because they not only show us the concerns about language held by members of the DLF, but they also show us that these members feel qualified to arbitrate on language usage and to decide on what is 'proper' usage.

\title{
Are these activities purist?
}

All of the above activities could not be said to be purist per se. Active attempts to ensure the continued use of French are different from attempts to remove English vocabulary from the French language, for example. However, competitions such as those outlined above do show at least an element of prescriptivism - an attempt to get the French-speaking youth to improve their written French - and the relevés d'écoute and the musée d'horreurs show an active purism. For example, the areas noted in the relevés all deviate from the standard, 'correct' form of the language, and the corrections given aim to protect the language from these deviations (or corruptions).

\subsubsection{Journal}

The DLF has a quarterly journal, La revue DLF, which publishes articles about language and also reproduces work published by the Académie française and the terminology commissions. For example, the regular columns L'Académie gardienne de la langue: Les emplois recommandés ou déconseillés and 
Acceptations et mots nouveaux reproduce terms taken from the $9^{\text {th }}$ edition of the Académie dictionary and new terms approved by the terminology commissions, respectively.

Taking a representative sample of 11 issues of the journal over three years (2006-2008), several major recurring themes can be discerned. Many articles show a concern about the use of French in the EU and other international institutions, and reflect the desire of the DLF to promote the use of French in the world. This is most often shown as a desire for multilingualism, as can be seen, for example, in the article Plurilinguisme : une utopie? (La Revue DLF $\mathrm{n}^{\circ} 220$, April-June 2006). Numerous other articles appear on this subject, and it is possible that that this ostensible desire for multilingualism masks another desire, which is for the French language to regain the importance it once held in Europe and the wider world. This may mirror the official language policy in France, which, although it has moved from the overt promotion of French as the European lingua franca to the promotion of multilingualism, does not in reality reflect a genuine interest in Europe's other languages (cf. Oakes 2002).

Other common themes are the 'correct' use of the French language, anglicisms and their use in French and the use of English encroaching that of French in many areas of France, such as business and culture. Many of the articles on these topics clearly indicate some purist traits. For example, articles outlining the correct use of one or another feature of the French language, such as Du bon usage des paranthèses (La Revue DLF $\mathrm{n}^{\circ}$ 225, July-Sept 2007) and Ah! Ce subjonctif! (La Revue DLF $\mathrm{n}^{\circ} 227$, Jan-March 2008), reflect the purist idea outlined above, that only one form of the language is the correct form. Similarly, articles referring negatively to the use of English terms in French, such as Bas coût ou coup bas (La Revue DLF $\mathrm{n}^{\circ}$ 229, July-Sept 2008), where the term 'low cost' is condemned as 'massacring' the French language, reflect the purist idea that change to French equals contamination, and that the language must be preserved from this contamination.

Naturally, not all of the articles show such purist tendencies; however, the general themes covered in the journal tend to centre on the areas outlined and thus the general tone of the journal could be said to be fairly purist.

\subsection{Avenir de la langue française (ALF)}

\subsubsection{Overview}

The ALF was founded in 1992 and its aim is the defence and the promotion of the French language. More specifically, it aims to ensure that the Loi Toubon of 4 August 1994 is enforced in France and to fight for the continued use of French, particularly in international organizations such as the UN and the European Union. The association states that it gathers together those who 'refusent de se soumettre à la domination absolue de la "langue dollar" et qui veulent continuer à vivre en français en France, dans les pays francophones, dans une Europe plurilingue, dans un monde riche de toutes ses langues et cultures'. Its main preoccupations include the right to work and consume in French in France, to use French in the institutions of European Union and to retain the choice of foreign languages available to children at school. $^{5}$

Unlike the DLF, the ALF does not specifically mention the use of foreign terms in French or refer to the language in itself (to its superiority, its clarity etc.). It sees the threat of English to be to the domains in which French is used rather than to the structure of the language. Examining the activities of this society will allow us to determine whether or not the ALF also shows concerns about the influence of English on the language itself, or whether it really is concerned only with its continued use in all domains.

\subsubsection{Activities}

The ALF disseminates its opinions through the media as much as possible, and notifies the authorities of breaches of the linguistic laws. It also awards the prix de la carpette anglaise annually (discussed below), which is a good means of raising awareness as it is widely discussed in the general media. 
On its website, the ALF outlines various activities that it carries out in order to meet its aims. It organises various demonstrations and protests against conferences, films, ceremonies etc., that use English instead of French, such as the protest it staged, on 7 February 2003, against a conference at the École normale supérieur organised by the CNRS, called 'Space languages', at which it claims the only language used was English. ${ }^{6}$ It states that it works with several unions to ensure that the legal right to work in French in France is upheld, and undertakes direct actions against companies that infringe this legal right. For example, in 2003, in association with the SNPL (Syndicat national des pilotes de ligne), the DLF and Courrier Sud, it brought a case against Air France, because it obliges its air crew to use instructions written in English only. ${ }^{7}$ It also campaigns to try and ensure that French is used for teaching, cultural purposes (music, cinema, television etc.) and in the scientific domain in France. For example, in 2008 it campaigned against what it sees as the increasing use of English to teach French university students, and against any exams being held even partially in English, which it sees as being 'en infraction flagrante à l'article premier de la loi du 4 août 1994', and awarded Valérie Pécresse, minister for Higher Education, the carpette anglaise (see below) for facilitating this same use of English. ${ }^{8}$

Similarly to the DLF, a section of the ALF website is dedicated to a musée des horreurs where photos showing English terms being used in various advertisements, shop notices etc. are shown. This section of the website is one of the few sections where the use of anglicisms is targeted, as many of the pictures in question involve one English term or phrase only. For example, one of the pictures shows a Credit Agricole bank card highlighting the MasterCard logo and the text 'Electronic use only' which appears below it, and another shows a Nike ad, with the slogan There's no finish line. The language accompanying these photos is highly sarcastic, and the companies in question are often accused of wanting to appear modern. ${ }^{9}$

\subsubsection{Journal}

The ALF has a journal which comes out 3 times a year. Taking a representative sample of nine issues of the journal over three years (2006-2008), we can see that the articles mainly concentrate on where and how much the French language is used, rather than on the actual structure of the language itself or the effect of English on the language, as with the DLF. One of the major themes dealt with in the journal is the use of French in France and in the European Union, and many of the articles highlight the concern shown by the ALF about the increasing spread of English in many areas and the corresponding marginalisation of French. For example, the article Révolter-vous urges readers not to give into the spreading anglicisation of France in the workplace and in the cultural domain (Bulletin d'ALF $\mathrm{n}^{\circ} 27$, February 2006) and Une petition en faveur de l'édition scientifique en français (Bulletin d'ALF $\mathrm{n}^{\circ} 33$, March 2008) promotes a petition against French scientists publishing in English. Another common theme is the promotion of multilingualism in Europe, as highlighted by the article Français et Allemands unis dans la défense du multilinguisme dans l'UE (Bulletin d'ALF $\mathrm{n}^{\circ} 27$, February 2006).

Although not a major theme in this journal, some articles discuss the use of anglicisms in French, and those that do show a highly purist rhetoric. For example, the article La langue française en danger (Bulletin d'ALF $\mathrm{n}^{\mathrm{O}}$ 31, June 2007) claims that 'notre langue vit un véritable Verdun culturel', which highlights the purist idea that the language is being attacked (that is, corrupted) and needs protecting. However, in general, the articles in this journal appear to be more concerned with the decreasing use of French in various domains rather than with the type of French used.

\subsection{La Carpette anglaise}

The prix de la carpette anglaise is a prize 'd'indignité civique' awarded annually to a member of the French 'elite' 'qui s'est particulièrement distingué par son acharnement à promouvoir la domination de l'anglo-américain en France et dans les institutions européennes au détriment de la langue française'. ${ }^{10}$ This prize was created in 1999 by four different language societies: the DLF, the ALF, the Association pour la sauvegarde et l'expansion de la langue française (ASSELAF) and the Droit de Comprendre (DDC). 
Recent recipients of this prize have included, in 2008, Valérie Pécresse, minister for Higher Education and Research, for having announced that 'le français était une langue en déclin et qu'il fallait briser le tabou de l'anglais dans les institutions européennes'; in 2007, Christine Lagarde, Finance minister, who communicates with her departments in English; and in 2005, France Télécom, for having introduced services and products with English names, such as Business Talk, Live-Zoom and Family Talk.

The language used to describe this prize is extremely emotive:

Le prix de la Carpette anglaise distingue plus spécialement les déserteurs de la langue française qui ajoutent à leur incivisme linguistique un comportement de veule soumission aux diktats des puissances financières mondialisées, responsables de l'aplatissement des identités nationales, de la démocratie et des systèmes sociaux humanistes. $^{11}$

Here language is equated directly with national identity. The use of the word 'déserteur' appears to class those who 'neglect' their language on a par with army deserters, and links their lack of 'civic linguistic responsibility' to a levelling of national identity. The fact that both the DLF and the ALF take part in judging and awarding this prize shows their purist intent.

\subsection{Legal proceedings}

The DLF and the ALF are approved by the ministry of Culture and Communication to appear in court in certain cases of infringement of the Loi Toubon of 4 August 1994 (decree n 95-240 of 3 March 1995), in particular those cases concerning consumer information. ${ }^{12}$ Both societies are part of Droit de Comprendre (DDC), which was set up in October 1994 to coordinate the activities of all language societies working to ensure that French consumers' linguistic rights are respected. Other members of the DDC include the Association pour la sauvegarde et l'expansion de la langue française (ASSELAF), the Cercle littéraire des écrivains cheminots (CLEC) and the Alliance Champlain. ${ }^{13}$

The DDC takes legal action against public or private companies that do not respect the consumer or the user. Examples of successful litigation include the following:

- Mephisto was given two fines by the higher level court in Metz in 2001 for using English slogans without providing a translation.

- GEMS was fined 580000 euro by the Versailles court of appeal. Amongst other things, the company was given notice that it was obliged to translate software displays, documents relating to staff training, hygiene and safety and documents relating to products produced by the company. ${ }^{14}$

\section{Thomas's questionnaire}

The questionnaire devised by Thomas to provide a profile of purism in a given country is in the form of a checklist composed of eighteen questions (Thomas, 1991: 191-2). Some questions require more detailed analysis and responses than others. The questionnaire is reproduced below. Each question will be answered with regard to the two language societies outlined above, and will refer to parts of Thomas's general framework in more detail where this is deemed necessary. As this study only involves two language societies, it is naturally not an attempt to provide a general profile of purism in France. However, applying the questionnaire in this way to different sectors of language activity in France will allow a fuller picture of the linguistic purism in France today to be built up bit by bit.

Note that questions 14 to 18 are excluded from this analysis, as they relate to the effects of the purism in question over time and to the overall effects of the purism. As this is a synchronic study, the effects over time cannot be measured and as we are looking at only a small section of potential puristic activity in France, we cannot yet refer to any overall effects. 


\subsection{The questionnaire}

1. To what extent does the purism take non-puristic concerns into consideration in developing its ideology? Not at all To some extent To a great extent

2. Is the puristic orientation external or internal? External Internal Both

3. If both, which orientation is the dominant one?

4. If the threat is wholly or partially external, which of the following describes the threat more clearly? Non-specific Specific

5. If specific, is more than one language involved? Yes No

6. If 'No', which of the following describes the language most closely? From the same diasystem Related Unrelated

7. Which of the following best describes the position of the threatening languages vis-à-vis the language where the purism is located?
In the same state
In another state

8. Has the threatening language ever served as a language of culture for the speakers of the language where purism is involved?

Yes No

9. If the threat is internal, which planes and which poles are involved?
élitist
ethnographic
archaising
reformist

10. Which of the modes of the implementational cycle have been completed in the purism under review?

Censorship Eradication Prevention

Replacement Reception Evaluation

11. Is the purism primarily or exclusively directed at the lexical level? Yes No

12. If 'Yes' and the lexical purism is xenophobic, into which of the categories given in Figure 10 (1991: 172) do the targets fall?
Mild
Moderate
Extreme

13. Similarly, into which of the categories given in Figure 11 do the preferred replacements fall? Mild Moderate Extreme

\subsection{Application of the questionnaire to the language societies}

\subsubsection{Puristic and non-puristic concerns}

The first question asks to what extent the purism takes non-puristic concerns into consideration in developing its ideology. Briefly, non-puristic concerns refer to rational concerns, which are motivated by instrumental and ethical attitudes and puristic concerns refer to non-rational concerns, which are motivated by affective and traditionalist attitudes (Thomas, 1991: 37).

Affective attitudes include an opposition to foreign influences on the native language and traditional attitudes are based on a reverence for custom (for example, a wish to keep the language in an unchanged, traditional form). Non-rational attitudes are also associated with the notion of nationalism. Nationalism is based on the idea that the national culture is unique and irreplaceable and only the national language can adequately serve as a symbol of self-identification with this national culture (Thomas, 1991: 43). It is clear that both the DLF and the ALF show non-rational (that is, puristic) concerns in their ideology. Both societies make strong links between the French language and the French nation, as can be most clearly seen in the language used to describe the Prix de la carpette anglaise. However, the DLF shows more concern with the purity of the language itself than the ALF, that is, it shows greater opposition to English terms in French and also a greater reverence for custom (cf. the relevés d'écoute and the main journal themes). It can thus be seen to base its ideology more strongly on non-rational concerns than the ALF. 
Instrumental attitudes are based on practical criteria, with the aim of achieving some goal, and ethical attitudes are based on the inclusion of the whole speech community (Thomas 1991: 37). Both societies appear to show some rational concerns. For example, enriching the language so that it can fulfill all of the functions it is required to carry out could be seen as an instrumental concern. The DLF explicitly states as one of its aims the enrichment of the French language so that it can be adapted to modern life. The 'intelligibility argument', which is used to claim that language elements unknown to the broad masses should be avoided as they hamper intelligibility (Thomas 1991: 49) could be seen as an ethical concern. This argument appears to underlie much of the ideology of the ALF; in particular, it strives to promote the use of French in all domains to avoid the exclusion of some members of the community.

Thus we can see that although both societies show both puristic and non-puristic tendencies, the DLF is more markedly purist than the ALF.

\subsubsection{Puristic orientation}

Questions two to eight concern the orientation of the purism. An understanding of the different types of purism outlined by Thomas is necessary to answer this question. Thomas makes a general distinction between 'external' purism and 'internal' purism (Thomas 1991:81), but he also distinguishes several types of purism within the internal orientation, including archaising, ethnographic, elitist and reformist purism. The external orientation only has one type of purism: xenophobic purism.

\section{Internally-oriented purism}

Archaising purism involves looking towards the past. This is often shown by

An attempt to resuscitate the linguistic material of a past golden age, an exaggerated respect for past literary models, and excessive conservatism towards innovations or a recognition of the importance of literary tradition.

(Thomas, 1991:76)

Ethnographic purism often looks towards rural dialects for new words, as these are seen as being in some way purer than the standard language (Thomas 1991:76). Élitist purism, on the other hand, is negative towards these rural dialects or any non-standard speech. Similarly to archaising purism, which looks towards a past 'perfect' model, it can be based on the belief that language can be perfected (Thomas, 1991:78). Reformist purism involves 'a conscious effort to reform, regenerate, renew or resuscitate a language' and is thus important in the creation of standard languages and 'adapting the language for its role as a medium of communication in a modern society' (Thomas, 1991:79).

\section{Externally-oriented purism}

Externally-oriented or xenophobic purism involves 'removing or replacing foreign elements, whether their source is specified (targeted xenophobia) or unspecified (general xenophobia)' (Thomas, 1991:80). ${ }^{15}$

From the analysis of the language societies above, it is reasonable to assert that the puristic orientation is both external: the objection to the use of anglicisms in French (targeted xenophobia), and internal: the preoccupation with preserving French in its ideal state. However, it would appear that the two societies differ slightly. The ALF leans strongly towards an externally-oriented purism whereas the DLF shows both internal and external purism. Although the stronger emphasis on the external orientation, it also shows archaising and elitist purism. For example, it clearly refers to the historical importance and value of the French language, and is concerned with the 'correct' usage of the language, that is, the language in its 'perfect', standard form. The threat is specific and involves one language only (Anglo-American) and this language is from an unrelated diasystem. The threatening language is in another state, and until this period, it has never served as a language of culture for French speakers, in fact, French was more likely to have been regarded as the language of culture in Europe for a long time. 


\subsubsection{Purification process}

Question 10 relates to the stages of the purification process outlined by Thomas. Thomas outlines several stages which make up what he terms the "purification process", including recognition of need, identification of targets, censorship, eradication, prevention, replacement, reception and evaluation (Thomas, 1991:84).

\section{Recognition of need}

As Thomas states, purism cannot occur without 'consciousness of supposed deficiencies' (ibid.), that is, without purists deciding that the language is in need of purification or, at least, is in danger of becoming impure (Thomas, 1991:85).

\section{Identification of targets}

At this stage, purists decide what categories of words will be targeted as unsuitable or undesirable.

Note that, according to Thomas, the above two stages of the purification process are essential for the later stages to take place, which is why they are not included in question 10 (Thomas, 1991: 88).

\section{Censorship}

'Censorship purism' is most closely identified with formal written discourse, as writing is less spontaneous and involves more premeditation than speech. However, it also involves speakers correcting themselves or others when they notice foreign words (or words defined as unacceptable during the identification phase) being used (Thomas, 1991:88-90).

This type of purism is evident in the relevés d'écoute compiled by the DLF. The words that are being censored are listed as incorrect. This type of purism is not shown by the ALF, however.

\section{Eradication}

According to Thomas, this is the activity most commonly associated with purism, and it involves removing the unwanted elements established during the identification stage. Thomas also states that eradication is symptomatic only of quite extreme purism, because the removal of well-established foreign words requires much more effort than stopping the entry of new words (Thomas, 1991:91).

This type of purism is clearly evident in the relevés d'écoute compiled by the DLF and in many of the articles published in their journal. It is also evident in the musée d'horreurs sections of both the DLF and ALF websites. By choosing to correct language in the relevés d'écoute, explaining the 'correct' means of using various French structures in articles, and highlighting anglicisms in photos and advertisements, they are clearly trying to remove the unwanted, 'incorrect' or impure elements.

\section{Prevention}

This stage involves protecting the language from elements which have not yet entered it. Thomas claims that this type of purism does not occur very frequently, and usually only when a language academy of some sort tries to invent appropriate terms for new objects or concepts before the general public has had a chance of using non-native terms (Thomas, 1991:91-93).

This stage does not appear to be evident for either society.

\section{Replacement}

Thomas sees this as one of the most important stages of all purism, as "the provision of an acceptable alternative to the elements defined as undesirable is an essential component of all active purism". This stage usually occurs at the same time as the identification and eradication stages. However, sometimes purists are content merely to suggest a replacement without insisting on the foreign term being purged (Thomas, 1991:93-94). 
Again, the relevés d'écoute compiled by the DLF show replacements for the anglicisms that they note. Many of these replacements are those provided by the terminology commissions. The ALF, however, does not show evidence for this stage.

\section{Reception}

This stage refers to the reaction of the speech community to the suggestions and replacements proposed by purists. The reaction of these speakers often determines whether or not the purist endeavour will be successful (Thomas, 1991:95-97).

This stage is not easily measured for either language society, as it is difficult to know how many members of the wider speech community are aware of their activity. An aim of future research in this area is to attempt to gather information on this question.

\section{Evaluation}

This stage involves the evaluation of all the previous stages (or such of them as may have occurred during a particular purification attempt) either by those instigating the purism or others. If it is positive, then the puristic intervention 'may be pronounced successful and the process is more or less complete'. However, if it is negative, then the whole attempt at purism might either be abandoned or else new targets may be identified and purism may continue with a new orientation (Thomas, 1991:98-99).

This stage is difficult to evaluate, as we have no means of finding out how successful attempts by the language societies to eradicate or replace terms are. Details of legal processes won by the language societies allow for some evaluation of the success of the puristic endeavour, but as activities such as this are not provided for in Thomas's purification process, they cannot be evaluated here.

\subsubsection{Linguistic level of purism}

Question 11 refers to the linguistic level on which the purism takes place. Thomas claims that examples of purism can be found on all linguistic levels, (phonological, morphological, syntactic, lexical and orthographic). However, he does make a distinction between unmarked purism (purism operating at the lexical level) and marked purism (purism operating at the levels of smaller or larger linguistic segments) and thus sees lexical purism as the archetypal type of purism.

This is borne out by the example of the language societies, as the purism is largely directed at the lexical level (mainly at the use of English words in the French language), cf. the relevé d'écoutes and the musée d'horreurs above.

\subsubsection{Main targets of purism}

Question 12 refers to the types of word which are targeted by the lexical purism. Thomas claims that the lexical elements most frequently targeted by purism are loanwords, internationalisms, calques, neologisms and dialectisms (Thomas, 1991:68). He sees loanwords as being the most prone to puristic intervention because they are the most readily noticeable borrowed elements and often remain relatively unassimilated so that they appear foreign to native speakers. Calques, on the other hand, are often tolerated where loan words from the same language are not, perhaps because calques, even those consciously created to replace loan words, are not clearly foreign, and can pass unnoticed by many (perhaps even most) speakers (Thomas, 1991:23). Based on these targets of lexical purism, Thomas (1991: 172) outlines a scale of intensity for xenophobic purism. Mild xenophobic purism is directed at loanwords from a single, non-related source (either assimilated or unassimilated), moderate xenophobic purism is directed at loanwords from related languages (either assimilated or unassimilated) and internationalisms (either assimilated or unassimilated) and extreme xenophobic purism is directed at calques (loan translations and loan renditions). Also, inasmuch as the removal of well-established words presupposes a greater degree of puristic intensity, this should be assigned to the next, more intense category. 
The ALF does not provide much information on its puristic targets. It appears in general to be more concerned with the continued use of French than with the form of French used, although it does also object to anglicisms being used in French. However, it does so on a more general basis than the DLF, whose monthly relevé d'écoute clearly shows its targets. Taking the monthly lists for the year 2008, we see that the main targets are overwhelmingly unassimilated loan words from a single, non-related source (English), with very few examples even of assimilated loanwords and only one example of a calque (although this example was noted several times). Even though several of the loanwords noted are well established, including casting and design, it is clear that this can only be described as very mild purism.

\subsubsection{Replacements}

Question 13 refers to the type of replacement favoured for the words which are targeted. Thomas (1991: 173) provides a hierarchy of the preferred replacements as an index of puristic intensity. Mild xenophobic purism favours internationalisms, loanwords from related languages and calques as replacements, moderate xenophobic purism favours assimilated loans from related languages, calques conforming to native word-building laws, neologisms and dialectalisms as replacements and extreme xenophobic purism favours some loan renditions, neologisms, dialectalisms and archaisms as replacements.

The same sample of terms from the DLF's 2008 relevé d'écoutes almost exclusively suggests existing French terms as replacements. Only one neologism is given (courriel for email). This highlights the fact that the words being borrowed into French already have existing equivalents, that is, they are rarely entirely new concepts. It is interesting, however, that this situation does not fit into any of Thomas's types above. In other purist situations, it must also be the case that terms for existing notions are borrowed along with terms for new concepts. Again, this needs further exploration and potential expansion of Thomas's framework.

\section{Conclusion}

As has been shown above, the two major issues preoccupying the language societies are indeed the status and use of French in France and further afield and the influence of English on French. However, the importance of these issues varies within the societies. The DLF's activities show it to be far more concerned with the protection of the language from the intrusion of English terms than the ALF, which is mainly concerned with the promotion of French to ensure its continued use in all domains, that is, with its status. However, a concern with the status of a language cannot be classed as 'linguistic purism', at least not the purism outlined by Thomas, unless it manifests itself in actions to 'purify' the language itself. This is not the case with the ALF. Its motivations are mainly rational, it does not carry out any of the stages of Thomas's purification process, nor does it target any terms in particular or attempt to provide replacements, as does the DLF. It is questionable, therefore, whether the ALF can be described as a purist society, whereas it is clear that the DLF displays several purist traits, although even this only shows what Thomas would class as a mild form of purism.

However, the rhetoric of both societies is highly emotive and seemingly purist, with several references to cultural attack (cf. Verdun culturel above) and many highly negative references to an Anglo-American society apparently hell-bent on completely ousting the French language and culture to impose its own. It is thus difficult to see these societies as non- or very mildly purist. It may simply be that their targets are broader than merely the language itself, due to the specific situation in question, a situation which may not have been relevant when Thomas published his work (1991). Further, more in-depth research of other language societies is needed to explore this question further and to determine whether or not Thomas's framework needs expanding.

1 DLF, “Origine” (12/2009), < http://www.langue-francaise.org/Origine.php >

2 DLF, "Les Cercles" (12/2009), < http://www.langue-francaise.org/Administration.php\#cercles > 
3 DLF, “Musée des horreurs" (12/2009), < http://www.langue-francaise.org/Horreurs/Accueil.html > 4 DLF, "Relevé d'écoute" (12/2009), < http://www.langue-francaise.org/Releve_ecoute.php >

5 ALF, “Qui sommes nous ?” (12/2009), < http://www.avenir-langue-francaise.fr/articles.php?lng=fr\&pg=7>

6 ALF, “Actions" (12/2009), < http://www.avenir-langue-francaise.fr/articles.php?lng=fr\&pg=313 >

7 ALF, “Travail” (12/2009), < http://www.avenir-langue-francaise.fr/articles.php?lng=fr\&pg=316>

8 ALF, "Enseignement" (12/2009), < http://www.avenir-langue-francaise.fr/articles.php?lng=fr\&pg=317 >

9 ALF, “au Musée des horreurs" (12/2009), < http://www.avenir-langue-francaise.fr/articles.php?lng=fr\&pg=350 >

10 DLF, "Carpette anglaise" (12/2009), < http://www.langue - francaise.org/Articles Dossiers/Carpette historique.php >

11 ibid.

12 DGLFLF, “Rapport 2003” (12/2009), < http://www.dglf.culture.gouv.fr/rapport/2003/Premiere partie I.htm >

13 DDC, “Qui sommes nous” (12/2009), < http://droit-de-comprendre.perso.neuf.fr/Qui_sommes_nous.php >

14 ALF, "Législation linguistique" (12/2009), < http://www.avenir-langue-francaise.fr/articles.php?lng=fr\&pg=322 >

15 Note that the term xenophobic as used by Thomas is intended to denote aversion to foreign linguistic elements only and is not intended to imply racism of any kind.

\section{References}

Adamson, R. (2007). The Defence of French: A Language in Crisis?. Clevedon: Multilingual Matters.

Oakes, L. (2002). 'Multilingualism in Europe: An effective French identity strategy?'. Journal of Multilingual and Multicultural Development, 23 (5): 371-387.

Thomas, G. (1991). Linguistic Purism. London: Longman.

\section{Online references}

DLF (Défense de la langue française) $(12 / 2009)<\underline{\text { http://www.langue-francaise.org/ > }}$

ALF (Avenir de la langue française) $(12 / 2009)<\underline{\text { http://www.avenir-langue-francaise.fr/ }>~}$ 